DOI

\title{
НЕІНВАЗИВНА ОЦІНКА ФУНКЦІОНАЛЬНОГО СТАНУ СЕРЦЯ, СУДИН І ОРГАНІВ ТРАВЛЕННЯ ПРИ ПРИЙОМІ ЗМІШАНОЇ ЇЖІ В ПРАКТИЦІ СІМЕЙНИХ ЛІКАРІВ
}

๑Ю. І. Решетілов, С. М. Дмитрієва, Л. П. Кузнєцова, О. Ю. Васильченко, Н. М. Проценко, Т. В. Богослав, С. Г. Пузік, А. П. Курган, О. М. Стаценко,

О. Ф. Цаприка, Л. В. Таранюк, Л. Г. Зуєвич

Д3 «Запорізька медична академія післядипломної освіти МОз україни»

Мета дослідження - вивчити функціональний стан серцево-судинної системи та органів травлення при змішаному травленні в практиці сімейних лікарів.

Методи дослідження - прилади, що визначають електрофізичні властивості їжі та біологічні середовища людини. Змішана їжа - білки, жири, вуглеводи, макро- і мікроелементи. Прилади добового моніторування ЕКГ, АТ, ЧСС, сатурації. Прилад Ангіоскан, аероіонний комплекс (ЩИТ 3). Об'єктами дослідження були 30 здорових осіб і 1000 пацієнтів із захворюваннями органів травлення та серцево-судинної системи.
Результати дослідження. У обстежених здорових людей у відповідь на прийом змішаної їжі, а також роздільної їжі-білків, жирів, вуглеводів, відзначаються зміни функціонального стану травної та серцево-судинної систем $(P>0,05)$. У хворих з коморбідними станами в базальний і травний періоди відзначаються різного ступеня вираженості зміни показників функціонування серцево-судинної та травної систем ( $\mathrm{P}>0,05$ до $\mathrm{P}<0,05, \mathrm{P}<0,001)$.

Висновки: функціональну коморбідність серцево-судинної і травної систем необхідно враховувати при змішаному харчуванні і призначенні медикаментозної терапії. 